\title{
Family Business Values: analysis of its influence on family members' behavior
}

\author{
Los valores en la Empresa Familiar: análisis de su influencia en el \\ comportamiento \\ Maribel Rodríguez Zapatero • Magdalena Rodriguez Jiménez ${ }^{\mathrm{b}}$ \\ ${ }^{a}$ Departamento de Estadistica, Econometría, Investigación Operativa y Organización de Empresas, Universidad de \\ Córdoba, Córdoba (Spain) \\ ${ }^{b}$ Cátedra Prasa de Empresa Familiar, Universidad de Córdoba, Córdoba (Spain)
}

\section{A R T I C L E IN F O}

Article history:

Received 15-09-2012

Accepted 30-10-2012

Keywords:

Values

Behaviors;

Family business.

JEL codes:

M14

D A T OS ARTÍCULO

Historial:

Recibido 15-09-2012

Aceptado 30-10-2012

Palabras clave:

Empresa familiar

Valores

Comportamientos

Códigos JEL:

M14
A B S T R A C T

This research focuses on how values system of family business in Córdoba, moderates behavior within family business. 446 people belonging to 112 family firms answered a set of instrumental values and behaviors evaluated from one to five.

Results show significant correlations among variables that shape the values system as well as almost normal distribution for behaviors analyzed. The values system within a family firm act as a moderator of family business behavior. The instrumental values, guides needed for family firm survival, moderating behaviors are Ethic, cohesion and austerity. Ethic moderates communication and compromise. Cohesion affects confidence, acquiescence and cooperation meanwhile confidence and communication is moderated by austerity.

\section{R E S U M EN}

El objetivo perseguido en este estudio es analizar de qué forma el sistema de valores de la familia empresaria condiciona o modera los comportamientos de sus miembros. A tal efecto se diseñó un cuestionario respondido por 446 miembros de 112 empresas familiares. Los resultados obtenidos muestran correlaciones significativas entre las variables moduladoras del sistema de valores y distribuciones normales en los comportamientos analizados. Los valores, necesarios para garantizar la supervivencia de la empresa familiar, que moderan los comportamientos son la ética, la cohesión y la austeridad encontrándose relaciones significativas entre ellos y los comportamientos analizados.

\footnotetext{
*Autor de contacto.

Correoselectrónicos:es3rozai@uco.es,pu2rojim@uco.es
} 


\section{Values within the Family Business}

The family as an institution defines values, culture and ethic within it. This affirmation is shared by multiples authors having the family as the center of their investigations, Duh and Belak (2009). Following Bogod and Leach (2006) the family can be viewed as the dining room where the very first social reactions take place and therefore the confidence as well as the concept of family is built in this early stage. Even more, the family as a system establishes fundamental principles and core values reinforcing ethics and seeking long term survival (Belak, J. 2012).

The family business shows high level of compromise and moral behaviors, which can be explained by family social values. The family is the primary organization where rules are created and modify through generations (Euler, 2001). Family members, belonging to a same generation, share equal rules and values allowing the firm to take decision more rapidly (Pieper, T.M, 2010). This rapidness can be a competitive advantage for family business.

Fair Play produces compromise among family business members. Mutual transparency and honesty facilitate compromise and enable a transfer of energy and knowledge from individuals to the family firm. Cohesion within the family business has to do with the manner each member identifies him or herself with the family business project. As a member joins the family firm group his or her personal interests coincide with the family firms interests but as the family grows and new members join the group this interests coincidence undermines because of intrinsic motivations of each member (De Cremer and Van Dijk, 2002). Reach this point, it is important to distinguish between social cohesion and cohesion within procedures The family can inject cohesion to the group although some members could not agree in cognitive decisions (what to do) or in procedures decisions (how to do) (Zaccaro y McCoy, 1998). Cohesion can be view in a family level or in a family business level, but normally families links are emotional meanwhile business links are financial. Emotional links are related to the satisfactions of security, affiliation and belonging needs while financial links have to do currency, heritages and sharing profits. Success in family firms relies on the ethic compromise of its members, on fair play among family members and on cohesion.

The manner the value system is transmitted from one generation to the next one definitely affect ethic behaviors within the family firm. Not only founders affect entrepreneurial behaviors but also the family has a deep impact on them. (Steier, 2001) as well as on how the firm is organized, managed and transmitted (Hoffman and others, 2006).

Family business values have been deeply studied. Values within family business reinforce the family firm system, guide the decision process, enable compromise and align behaviors (Deal and Kennedy, 1982). These values can be transmitted in a formal way using family agreement (protocol), or informally by lead (Robertson, C.J., 2008). The existence of ethics values derives into good level of communication and confidence in family. Both, confidence and communication are crucial to generate effective coordination as well as strong links within the family firms that extend biologically talking (Bachman and Zaheer, 2006-2008)

Values can be classify into two categories; terminal values, which define desirable states or instrumental values which are ways to asses terminal values. Instrumental values are based on individual or group capacities and or competences (Hood, 2003). Terminal values are configured by tolerance, love, solidarity and forgiveness, which are the base for family business survival according to García-Marzá, D. 2005.

This research has focused on the way family business members share the same value system and if these values moderate or influence certain behaviors, conducts and attitudes. Conducts analyzed are opportunism and acquiescence. Communication and cooperation are conducts under study as confidence and compromise determine the set of attitudes analyzed. For instrumental values cohesion and austerity has been selected and ethic as well as fair play determine terminal values in this research. Firstly, this research paper explicit the moderator role of the instrumental values above 
described on family business members behaviors. Secondly descriptive statistical information obtained from a questionnaire filled in by 446 individuals belonging to 112 family firms is presented. Thirdly linear regression as a method is selected to run an analysis on how certain instrumental values influence or moderate particular behaviors to last with a discussion of the results obtained.

\subsection{Values as Behavior Moderators}

Tapies and Fernández (2010) typify values as moderators of family cohesion, as bases for family business sustainability as well as support for its own transmission to next generation in business. For these researchers, mentioned above, the values contributing to family cohesion are respect, loyalty, honesty and reputation. The premise in this research is that family cohesion influences communication and cooperation and therefore contributes to the family firm success. Following Tapies and Fernández the sustainability of a family firm relies on venture capacity, excellence, dedication, prudence and profitability. An effective governance of the firm and leading with transparency are conducts and behaviors that facilitate values transmission using valuable communication.

Values influence behaviors. Values are based on the sense of life individually perceived, and this sense of life influences attitudes, which determine a particular behavior that can be experimentally verify. Values are relatively stable during time. This perception is shown by Klein and Kellermans (2008) trying to interpret family firms behaviors motivate by non economic or financial issues. It is obvious how values are educational dependent, how values drives individual behavior and perceptions of an individual space or the own society (Rokeach, 1973). In our research this mentioned space is the family firm. The value system differs from one family firm to others. It also can differ among members belonging to the same family business.

Trust and communication are engines of intelligence relationship, with certain doses of motivation within the family business. Trust and communication are basic variables to achieve success in family business protocol (Rodríguez Zapatero and others, 2010). High level of intelligence relationship can be used as a predictor of probability of reaching family agreement, clearly affecting the future of the family firm (Rodríguez Zapatero and others, 2011). Rodríguez Alcaide and others (2007) showed high correlation between shared values and mutual trust, between mutual trust and communication, cooperation and compromise. This research mentioned studied the level of positive correlation among shared values, compromise and cooperation but did not go through the manner or way in which shared values influence behaviors.

The main objective pursued is to corroborate if the value system hold by the family firm affects o influences behaviors and attitudes. The hypotheses to verify are as follow:

H1: Values as ethic, fair play, cohesion and austerity influence behaviors such as communication, compromise, cooperation and opportunism.

$\mathrm{H} 2$ : Values as ethic, fair play, cohesion and austerity influence attitudes such as trust and acquiescence.

\section{The model}

The values under study are ethic, fair play, cohesion and austerity. The premise is that these values are moderating certain behaviors and conducts defined as communication, trust, compromise, cooperation, acquiescence and opportunism. Our general hypothesis is that these four values positively influence trust and communication and therefore determine a cooperative compromise as well as the presence of acquiescence in decision process. These values also act as barriers for opportunism within family firm. The ethic in the family would generate a positive attitude towards fair play and therefore would increase individual satisfactions and build trust and compromise which would lead into mayor cooperation, improving the value of the family firm. Our conjecture is that ethic and fair play are intimately related. Our objective is to determine, as said before in this paper, if these values influence certain behavior shown by family 
members. The designed paradigm is shown in figure1.

\section{Figure 1}

Relational paradigm among values, attitudes and behaviors.

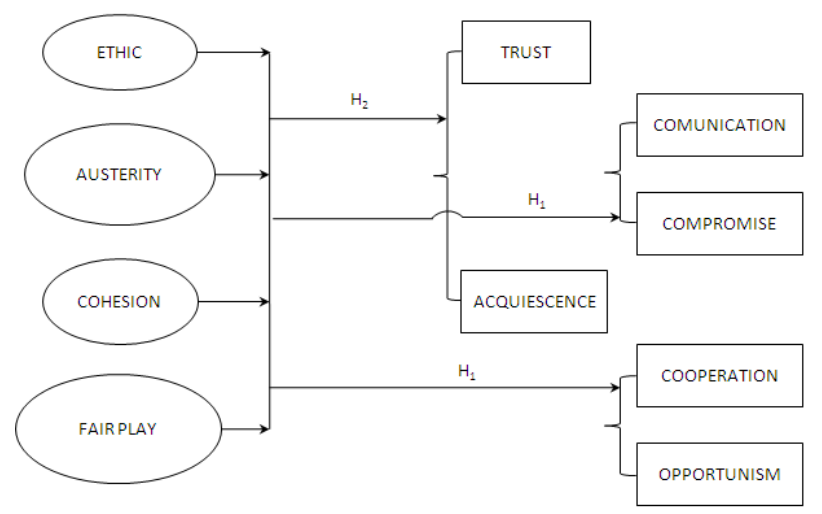

Values that can be shared by family members are values that lead to family firm success. These values are ethic, which has been assessed using the following statement "In order to achieve success in the family firm, each member has to be ethically compromised with business". Cohesion, being verify by the statement "In order to expand and achieve success in our family firm we have to be cohesive". Fair play is confirmed by the statement "In order to compromise ourselves to the family firm targets must exists fair play among us".

\section{Figure 2}

Relationship among values, conducts and objectives.

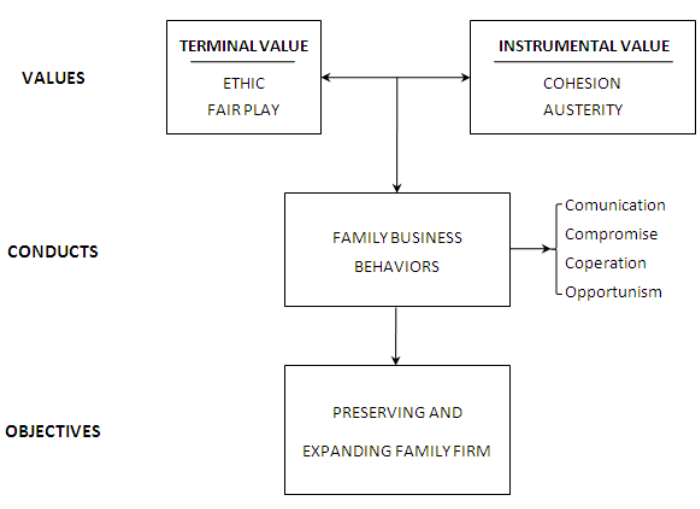

The statement "In order to expand and preserve the family firm we have to practice austerity" confirms austerity. All these values influence conducts, attitudes and behaviors of family business members. Our mental diagram is exhibited in figure 2.

\section{The sample}

The size of the sample is shaped by 446 people belonging to 112 family firms. These individuals were asked to fill in a questionnaire of 42 questions. When analyzing the sample by gender we encountered a mayor proportion of males $61 \%$ while female accounted for $39 \%$. When describing the sample by generation running the business we found that $59 \%$ family firms were in foundation stage, $40 \%$ in sibling stage and just $1 \%$ was ran by the third generation which means that inference of results and conclusions must applied to first and second generation only.

The statistical analysis has been applied to each family firm (unit under analysis) using the average value for each variable under study because the aim of this research is to search for values within family firms that moderate, influence in a mayor or minor way, family members behaviors. It makes no sense to mix values and behaviors from different family businesses. Each variable has been evaluated using a five-point Likert Scale, being one totally agree and five totally disagree.

\section{Declared behaviors}

Communication, compromise, cooperation and opportunism form the behaviors under analysis. All the behaviors mentioned above have been studied by construct. Six statements form the communication construct. Six statements having to do with personal perceptions define the compromise construct. Cooperation is verified using a five statements construct while the opportunism construct stays for three pronouncements. All statements are evaluated from 1 to 5 , being 1 totally agree and 5 totally disagree. These four constructs are shown in Appendix.

\section{Declared attitudes}


Table 1

Descriptive statistics for variables under study.

\begin{tabular}{|c|c|c|c|c|c|c|c|c|c|}
\hline & ETHIC & AUSTERITY & COHESION & FAIR PLAY & COMUNICACIÓN & OPPORTUNISM & COMPROMISE & TRUST & ACQUIESCENCE \\
\hline Number observations & 112 & 112 & 112 & 112 & 112 & 112 & 112 & 112 & 112 \\
\hline Min & 1,000 & 1,000 & 1,000 & 1,000 & 1,000 & 1,167 & 1,000 & 1,000 & 1,000 \\
\hline Max & 3,500 & 4,667 & 3,667 & 2,667 & 4,917 & 5,000 & 2,833 & 4,167 & 4,500 \\
\hline Freq. Min & 47 & 13 & 46 & 68 & 6 & 1 & 12 & 8 & 19 \\
\hline Freq. Max & 1 & 1 & 1 & 1 & 1 & 5 & 1 & 1 & 1 \\
\hline Range & 2,500 & 3,667 & 2,667 & 1,667 & 3,917 & 3,833 & 1,833 & 3,167 & 3,500 \\
\hline Median & 1,250 & 2,000 & 1,275 & 1,000 & 2,214 & 3,713 & 1,527 & 1,810 & 1,667 \\
\hline Average & 1,392 & 2,108 & 1,460 & 1,204 & 2,214 & 3,713 & 1,527 & 1,810 & 1,760 \\
\hline Variance & 0,236 & 0,615 & 0,331 & 0,128 & 0,659 & 0,564 & 0,163 & 0,335 & 0,356 \\
\hline Standard Deviation & 0,486 & 0,784 & 0,575 & 0,358 & 0,812 & 0,751 & 0,404 & 0,579 & 0,597 \\
\hline
\end{tabular}

Mutual trust is analyzed using a three statements construct while acquiescence construct is explained by two statements. All the statements are valued from 1 to 5 , being 1 totally agree and 5 totally disagree. (See Appendix)

\section{Results}

\subsection{Descriptive Statistics}

Descriptive statistics for terminal and instrumental values as well as attitudes, conducts and behaviors appear in table 1. As seen in the above table 1 , frequency is very high for variables such as Ethic, cohesion, fair play and honesty, which clearly indicates the great adhesion of family business members to these values. The consistency of the constructs analyzed have been verify by alpha Cronbach calculations obtaining values higher than 0.75 . All the variables were measured using a fivepoint Likert Scale. Each family firm has an average value for these variables. Average values close to one denote firm agreement with the values or behaviors under analysis. When it comes to analyses the results obtained for behaviors, the obtained ranking goes as follow: Cooperation (1.46), Compromise (1.53), Acquiescence (1.76), Trust (1.81), Communication (2.21), Nepotism (2.37) and Opportunism (3.71). The results were predictable as we have been able to corroborate by observation in many family business protocol processes advised in which most of the time the level of communication within the family business was less than the level of trust shown by its members (Rodriguez Zapatero and others, 2010). The results obtained for the values under investigation indicate a solid and intense adhesion to these values by the family firms. The average punctuation obtained for each value under investigation is as follow: Fair Play (1.20), Honesty (1.24), Ethic (1.39), Cohesion (1.46) and Austerity (2.11). All the statements are closed to one except for the value Austerity.

\subsection{Correlation Matrix}

The correlation matrix for values, as seen in table 2 clearly indicates that in family firms there is a conjoint of instrumental values that configure a structure of values needed for family business sustainability. All the correlations are statistically significant (alpha $=0.05)$, except for the pair Honesty-Ethic (0.028).

\section{Table 2}

\section{Values Correlation Matrix}

\begin{tabular}{|l|l|l|l|l|l|}
\hline VALUES & Ethic & Austerity & Cohesion & Fair Play & Honesty \\
\hline Ethic & 1 & 0.202 & 0.576 & 0.525 & 0.028 \\
\hline Austerity & 0.202 & 1 & 0.286 & 0.196 & 0.229 \\
\hline Cohesion & 0.576 & 0.286 & 1 & 0.699 & 0.223 \\
\hline Fair Play & 0.525 & 0.196 & 0.699 & 1 & 0.108 \\
\hline Honesty & 0.028 & 0.229 & 0.223 & 0.108 & 1 \\
\hline
\end{tabular}


As it can be observed in the figure 3 the correlation coefficients are significant and positive except for the pair compromiseopportunism (-0.241), which was an expected result because the existence of opportunism derives in less compromise damaging it.

\section{Figure 3.}

Values correlation coefficients

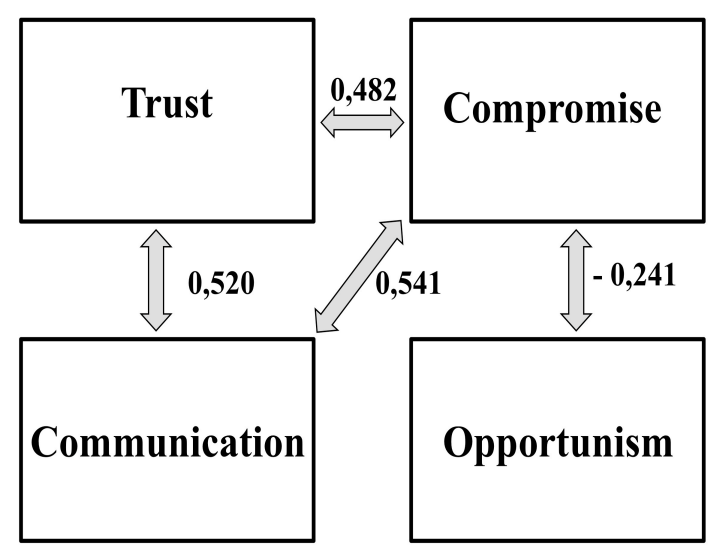

Taking the main objective pursued, the hypotheses to verify were as follow:

H1: Values as ethic, fair play, cohesion and austerity influence behaviors such as communication, compromise, cooperation and opportunism.

$\mathrm{H} 2$ : Values as ethic, fair play, cohesion and austerity influence attitudes such as trust and acquiescence.

\subsection{Regression analysis}

A regression analysis was conducted to verify our hypotheses. The results obtained show how trust and acquiescence are influenced by cohesion and austerity as it can be observed in the following expression:

Origin ordinates values represent the behaviors of family firm members without the influences of the value system. For each additional point in cohesion given by a family member a reduction in trust and acquiescence is registered. A maximum cohesion (1) will moderate trust in 0.33 while a minimum cohesion (5) undermines trust turning out with a

Table 3

Poner algo

TRUST $=0.9+0.330$ COHESION +0.277 AUSTERITY

\begin{tabular}{|c|c|c|c|c|}
\hline & \multirow[b]{2}{*}{ Amount } & \multicolumn{2}{|l|}{ Standard } & \multirow[b]{2}{*}{$\operatorname{Pr}>|t|$} \\
\hline & & Deviation & $\mathrm{t}$ & \\
\hline AUSTERITY & 0,277 & 0,088 & 3,164 & 0,002 \\
\hline COHESION & 0,330 & 0,088 & 3,774 & 0,000 \\
\hline
\end{tabular}

ACQUIESCENCE $=1.26+0.341 \mathrm{COHESION}$

\begin{tabular}{lllll}
\hline & & Standard & \\
COHESION & Amount & Deviation & $\mathrm{t}$ & $\operatorname{Pr}>|\mathrm{t}|$ \\
& 0,329 & 0,090 & 3,638 & 0,000
\end{tabular}

COMMUNICATION=1.23+0.228ETHIC +0.205 AUSTERITY

\begin{tabular}{lllll}
\hline \multicolumn{5}{c}{ Standard } \\
& Amount & Deviation & $\mathrm{t}$ & $\mathrm{Pr}>|\mathrm{t}|$ \\
\hline ETHIC & 0,228 & 0,093 & 2,466 & 0,015 \\
AUSTERITY & 0,205 & 0,093 & 2,213 & 0,029
\end{tabular}

COMPROMISE=1.4+0.415ETHIC

\begin{tabular}{lllll}
\hline \multicolumn{5}{c}{ Standard } \\
& Amount & Deviation & $\mathrm{t}$ & $\mathrm{Pr}>|\mathrm{t}|$ \\
\hline ETHIC & 0,415 & 0,087 & 4,760 & $<0,0001$
\end{tabular}

COOPERATION $=0.98+0.272 \mathrm{ETHIC}+0.324 \mathrm{COHESION}$

\begin{tabular}{lllll}
\hline \multicolumn{5}{c}{ Standard } \\
& Amount & Deviation & $\mathrm{t}$ & $\mathrm{Pr}>|\mathrm{t}|$ \\
\hline ETHIC & 0,272 & 0,100 & 2,721 & 0,008 \\
COHESION & 0,324 & 0,100 & 3,238 & 0,002
\end{tabular}




\section{Figure 4}

Regression analysis

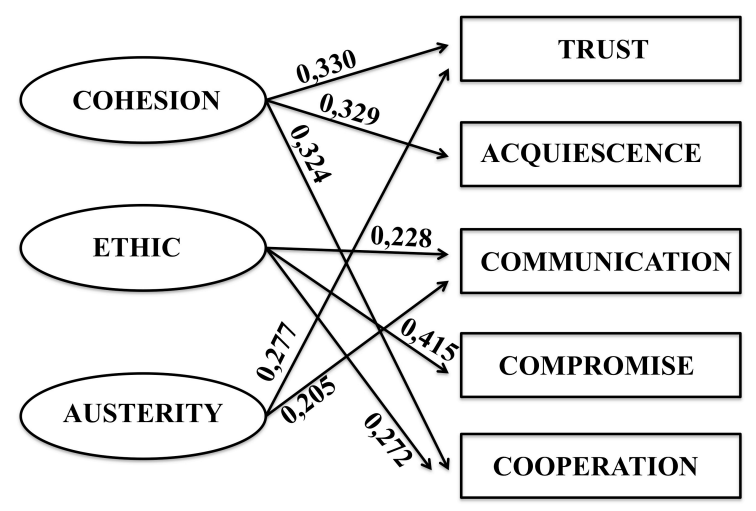

value of 2.705 .

The values cohesion, austerity, and ethic influence trust, acquiescence, communication, compromise and cooperation. The following figure 4 shows the values for the regression coefficients:

\section{Discussion}

This study tries to investigate the level in which family firms agree to certain statements that clearly influence the success for family business. When values are considered at an individual level, represent the moral of each member, but when these values are measured by groups stand for rules and habits acceptations of what can and cannot be done. The role play by the values has been deeply studied in different social disciplines (Rokeach, 1973).

Values influencing human behaviors have a complex structure. A value (Rokeach, 1973) is a permanent believe that specify if a behavior is or not admissible and therefore determine the individual personality and the practices in an organization. Nevertheless, an attitude is a mental state or a feeling related to something that is exteriorized with a behavior.

The values are a social abstract knowledge and guide our actions (Kahle, 1980). The values influence behaviors (Williams, 1979) and are guidelines to judge, prefer or choose certain behaviors. There are a lot of research papers having to do with the manner values influence behavior, but not too much in family business field.

The hypotheses previously established have been partially corroborated. The terminal value fair play does not appear as a moderator of attitudes or behaviors. This situation could be explained by the high significant correlation fair play shows with ethic as a terminal value as well as the instrumental value cohesion. In addition, not all the values influence behaviors and attitudes.

Ethic and cohesion values needed to achieve sustainability and success in family firms, moderate and influence behaviors. Concretely the value ethic acts as a moderator of communication, compromise and cooperation meanwhile cohesion has a bigger influence in cooperation than ethic does. Trust in family firms is moderated by cohesion and austerity. It is obvious and logic to think that the greater cohesion within family firm the greater trust, but it is no that clear how austerity can influence trust. But, if we consider limited trust is easy to deduct how an austere way of life can generate trust in those family members observing it. Communication is moderated by ethic and austerity. Logically thinking the presence of ethic within the family business derives in a better communication, but is not as easy to observe for austerity. Reached this point it is useful to remember, in order to understand how austerity affects or influences communication, that communication and trust are strongly linked, and in this case, both variables are moderated by austerity (Correlation coefficient between trust and communication stands for 0.541).

The cooperation as a behavior in the family business is influenced by ethic and cohesion. Opportunism, as expected, does not appear in those family businesses that have declared a great level of adhesion to the values, in fact opportunism has a negative correlation with communication (-0.287), compromise $(-0.241)$, trust $(-0.196)$ and acquiescence $(-0.262)$.

This investigation can be valuable for family business advisor trying to gain a better 
comprehension of the relations that take place between behaviors and values within the family business as well as building a paradigm to seek for agreement or fragmentation within the family business.

\section{Limitations}

This investigation has some limitations. Due to sample size, extrapolation to Spanish family firms is not possible, nevertheless the sample is random and represents $1,5 \%$ out of the total population from Cordoba, Spain allowing an inference process of how certain values influence or moderate some behaviors shown by family members within the family firm. Even though no confirmatory analysis has been practiced, the sample size is enough to run certain statistical processes such as consistency of constructs, correlation analysis and regression. The results obtained can help family business advisor improving the understanding of the complex and sometimes diffused world of relationships within family businesses.

\section{Conclusion}

The study has partially corroborated how certain values moderates and influences some family members behaviors. Ethic, as a terminal value, moderates behaviors such as communication, compromise, cooperation, meanwhile the value fair play does not play any role in this moderating process. Cohesion, as an instrumental value, influences trust and communication as austerity does too. The high level of adhesion to values and the congruency of behaviors to the values under study are verified.

\section{Bibliography}

Bachman, R. y Zaheer, A. (2006). Handbook of Trust Research. Edward Elgar.

Bachman, R. y Zaheer, A. (2008). Landmarkpaper on trust. Edward Elgar.

Belak, J.; Duh, M. y Milfeiner, B. (2012). The use of institutional measures for business ethics implementation in family and non-family business:
Does a family matter? African Journal of Business Management, 6 (1), 430-440.

Bodog, T. y Leach, P. (2006). Claves de la empresa familiar. Instituto de Estudios Económicos. Tablero. España.

De Cremer, D. y Van Dijk, E. (2002). Reactions to group success or failure as a function of identification level: a test of the goal-transformation hypothesis in social dilemmas. Journal of Experimental Social Psychology, 38, 435-442.

Deal, T. y Kennedy, A.A. (1982). Corporate Cultures: The Rites and Rituals of Corporate Life. Addison Wesley-Roadway Ma.

Euler, H.A., Holer, S. y Rohde, P.A. (2001). Relationship specific closeness of intergenerational family ties: Findings from evolutionary psychology and implications for model of cultural transmission. Journal of Cross Cultural Psychology, 32 (2), 147158.

Fink, M., Kessler, A., Duh, M., Belak, J. y Lang, R. (2009). Trust and successful coordination of SME co-operation and empirical study in Slovenia. Economic and Business Re. 2 (3), 205-216.

Fletcher, D., Melin, L. y Gimeno, A. (2012). Culture and values in family business: A review and suggestions for future research. Journal of Family Business Strategy, (3), 127-131.

García-Marzá, D. (2005). Trust and dialogue: Theoretical approach to ethics auditing. Journal of Business Ethics, 57 (3), 209-19.

Goel, S., Mazzola, P., Phan, P.H., Pieper, T.M., y Zachary, R.M. (2012). Strategy, ownership, governance and sociopsychological perspectives on family business from around the world. Journal of Family Business Strategy, (3), 54-65.

Hoffman, J., Hoelscher, M. y Sorenson, R. (2006). Achieving Sustained Competitive Advantage: A Family Capital Theory. Family Business Review, 19 (2), 135-145.

Hood, J.N. (2003). The relationship of leadership style and CEO values to ethical practices in organizations. Journal of Business Ethics, 43 (4), 263-73.

Kahle, L.R. (1980). Stimulus condition selfselection by males in the interaccion of locus of control and skill-chance situations. Journal of Personality and Social Psychology, 38, 50-56.

Klein, S.B. y Kellermans, F.W. (2008). Understanding the non-economic motivated 
behavior in family firms: An introduction. Family Business Review, 20 (2), 121-125.

Pieper, T.M. (2010). Non Solus: Toward a psychology of family Business. Journal of Family Business Strategic, (1), 26-39.

Robertson, C.J. (2008). An analysis of 10 years of business ethics research in Strategic Management Journal. Journal of Business Ethics, 80, 745-53.

Rodríguez Alcaide, J.J., Rodríguez Zapatero, M. y Rodríguez Jiménez, M. (2007). La constelación de la red familiar relacional. Cuaderno $\mathrm{n}^{\circ} 5$ de Investigación. Cátedra PRASA de Empresa Familiar. UCO. España.

Rodríguez Alcaide, J.J., Rodríguez Zapatero, M. y Rodríguez Jiménez, M. (2007). Transparencia informativa y conflictos de funcionalidad en la empresa familiar. Cuaderno $\mathrm{n}^{\circ} 6$ de Investigación. Cátedra PRASA de Empresa Familiar. UCO. España.

Rodríguez Zapatero, M., Rodríguez Jiménez, M. y Rodríguez Alcaide, J.J. (2010). Interpretación de la familia empresaria. Capítulo 2 (pp. 77-97). Colección Cátedra PRASA de Empresa Familiar. UCO. España.

Rodríguez Zapatero, M., Rodríguez Jiménez, M. y Rodríguez Alcaide, J.J. (2011). Fundamentos del modelo IR, Inteligencia relacional, como predictor del futuro pacto en la familia empresaria. Cuaderno $\mathrm{n}^{\mathrm{o}} 14$ de Investigación. Cátedra PRASA de Empresa Familiar. UCO. España.

Rokeach, M. (1973). The nature of human values. Free Press N.Y.

Steir, L.P. (2001). Family firms plural forms of governance and the evolving role of trust. Family Business Review, 14 (4), 353-367.

Tapies, J. y Fernández, M. (2010). Values and longevity in family business: evidence from a crosscultural analysis. Working-Paper, 866. July.

Williams, R.M.J. (1979). Change and stability in values and value systems: a sociological perspective en M. Rokeach editor de Understanding human values individual an societal. Free Press N.Y.

Zaccaro, S.J. y McCoy, M.C. (1998). The effect of task and interpersonal cohesiveness on performance of a disjunctive group task. Journal of Applied Social Psychology, 18 (10), 837-851. 
APPENDIX

\section{COMMUNICATION}

1) We communicate any important thing within the family business

2) We met in council to see the evolution of sales and business progress

3) We met to discuss family business financial issues.

4) We met to address retribution issues to family and non family members.

5) We met to decide new investments

6) We give our own opinions about family business progress.

\section{COMPROMISE}

members

1) I have a compromised relationship among family business

2) I want this relationship last for ever.

business

4) I feel highly motivated to keep working for my family

5) Maintaining compromise within family business members is very important for me.

6) We are all compromised with the family firm.

7) My compromise is based on trusty relationship

\section{COOPERATION}

1) Level of cooperation among different areas in your family business

2) When it comes to follow rules or given paths

3) Sharing clear information among different business areas

4) When it comes to balance private life with work.

5) When training new generation entering the family business

\section{OPPORTUNISMS} compromised

1) There is always a family business member not

2) Information is changed for those running the family business seeking their own benefit.

3) Some family business members use their positions in the family firm for their own convenience.

\section{ACQUIESCENCE}

1) I follow the family business leader without any problem

2) I normally argue family business decisions

\section{TRUST}

1) When the family business takes risk we trust the operations

2) Remunerations in our family business are based on responsibilities and contributions.

3) I trust my family business leader.
Totally agree

Totally disagree

$\begin{array}{lllll}1 & 2 & 3 & 4 & 5 \\ 1 & 2 & 3 & 4 & 5 \\ 1 & 2 & 3 & 4 & 5 \\ 1 & 2 & 3 & 4 & 5 \\ 1 & 2 & 3 & 4 & 5 \\ 1 & 2 & 3 & 4 & 5\end{array}$

Totally agree

Totally disagree

$\begin{array}{ccccc}1 & 2 & 3 & 4 & 5 \\ 1 & 2 & 3 & 4 & 5 \\ 1 & 2 & 3 & 4 & 5 \\ 1 & 2 & 3 & 4 & 5 \\ 1 & 2 & 3 & 4 & 5 \\ 1 & 2 & 3 & 4 & 5 \\ \text { Total cooperation } & & \end{array}$

$\begin{array}{lllll}\mathbf{1} & \mathbf{2} & \mathbf{3} & \mathbf{4} & \mathbf{5} \\ \mathbf{1} & \mathbf{2} & \mathbf{3} & \mathbf{4} & \mathbf{5} \\ \mathbf{1} & \mathbf{2} & \mathbf{3} & 4 & \mathbf{5} \\ \mathbf{1} & \mathbf{2} & \mathbf{3} & 4 & \mathbf{5} \\ \mathbf{1} & \mathbf{2} & \mathbf{3} & 4 & 5\end{array}$

Totally agree

Totally disagree

$\begin{array}{lllll}1 & 2 & 3 & 4 & 5 \\ 1 & 2 & 3 & 4 & 5 \\ 1 & 2 & 3 & 4 & 5\end{array}$

Totally agree

Totally disagree

$\begin{array}{lllll}1 & 2 & 3 & 4 & 5 \\ 1 & 2 & 3 & 4 & 5\end{array}$

Totally agree

Totally disagree

\begin{tabular}{|c|c|c|c|}
\hline 1 & 2 & 3 & 4 \\
\hline 1 & 2 & 3 & 4 \\
\hline & 2 & 3 & 4 \\
\hline
\end{tabular}

